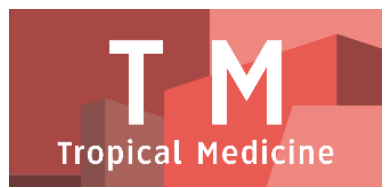

PAPER - OPEN ACCESS

\title{
Penilaian Pengetahuan, Persepsi Dan Kepercayaan Masyarakat Kota Medan Terhadap Penggunaan Antibiotik
}

$\begin{array}{ll}\text { Author } & : \text { Khairunnisa } \\ \text { DOI } & : 10.32734 / \mathrm{tm} . v 111.73\end{array}$

Paper Page : $291-296$

Volume 1 Issue 1 - 2018 TALENTA Conference Series: Tropical Medicine (TM)

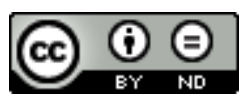

This work is licensed under a Creative Commons Attribution-NoDerivatives 4.0 International License.

Published under licence by TALENTA Publisher, Universitas Sumatera Utara
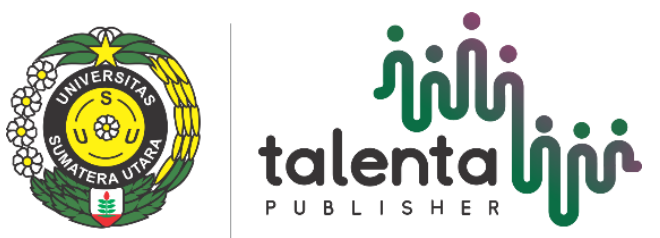


\title{
Penilaian Pengetahuan, Persepsi Dan Kepercayaan Masyarakat Kota Medan Terhadap Penggunaan Antibiotik
}

\author{
Khairunnisaa*, Hari Ronaldo Tanjunga dan Imam Bagus Sumantria \\ Fakultas Farmasi, Universitas Sumatera Utara 20155, Indonesia \\ nisa152@yahoo.com
}

\begin{abstract}
Abstrak
Antibiotik merupakan salah satu jenis obat yang sering digunakan dalam pengobatan penyakit. Resistensi terhadap antibiotik menjadi masalah besar diseluruh dunia. Resistensi terhadap antibiotik ini sangat berkaitan dengan kesalah pahaman terhadap penggunaan antibiotik oleh masyarakat. Penelitian ini bertujuan untuk mengetahui bagaimana pengetahuan, persepsi dan kepercayaan masyarakat Kota Medan terhadap penggunaan antibiotik. Penelitian ini merupakan penelitian Cross sectional dan dianalisis secara deskriptif untuk menilai pengetahuan, persepsi dan kepercayaan masyarakat terhadap penggunaan antibiotik. Sebanyak 98 orang responden terlibat dalam penelitian ini, mayoritas wanita (51\%), usia 43-54 tahun (36,7 \%), tingkat pendidikan perguruan tinggi $(44,9 \%)$ dan pekerjaan wiraswasta $(43,9 \%)$. Hasil penelitian ini mendapati bahwa sebanyak $82(83,7)$ masyarakat mengetahui bahwa antibiotik merupakan obat yang digunakan untuk membunuh bakteri, tapi hanya 16 $(16,3 \%)$ dari mereka bahwa antibiotik tidak digunakan untuk membunuh virus. Penelitian ini juga mendapati bahwa masyarakat mempunyai pengetahuan yang rendah mengenai penggunaan dan efek samping dari antibiotik $(<60 \%)$. Mengenai resistensi sebanyak 65,4\% masyarakat mengetahui penggunaan antibiotik yg tidak teratur dapat menyebabkan resistensi tapi rendah mengenai lama penggunaan antibiotik. Hasil penelitian ini juga mendapati bahwa masih terdapat banyak kesalahpahaman persepsi dan kepercayaan masyarakat terhadap penggunaan antibiotik. Berdasarkan hasil penelitian ini dapat disimpulkan, bahwa pengetahuan, persepsi dan kepercayaan masyarakat mengenai antibiotik masih sangat rendah dan perlu dilakukan usaha untuk meningkatkan pengetahuan dan pemahaman mereka mengenai antibiotik.
\end{abstract}

Kata Kunci: antibiotik, resistensi, pengetahuan, persepsi, kepercayaan,

\section{Pendahuluan}

Antibiotik merupakan salah satu jenis obat yang sering digunakan dalam pengobatan penyakit. Resistensi terhadap antibiotik menjadi masalah besar diseluruh dunia baik negara berkembang ataupun negara yang sedang berkembang (Grigoryan et al., 2007; Radyowijati and Haak, 2003). Resistensi terhadap antibiotik ini sangat berkaitan dengan kesalah pahaman terhadap penggunaan antibiotik oleh masyarakat. Di Eropa, beberapa penelitian menunjukan bahwa peningkatan resisten terhadap antibiotic berkaitan dengan konsumsi yang tinggi di masyarakat, hal ini disebabkan ketidak rasionalan penggunaan obat dan kurangnya edukasi pengenai antibiotik terhadap pasien (Goossens et al., 2005; Franco et al., 2009). Kesalahpahaman terhadap antibiotik di masyarakat sehingga mendorong tingginya permintaan pasien untuk meresepkan antibiotik dan penggunaan antibiotik tanpa resep oleh masyarakat (Andre et al., 2010). 
The World Health Organization (WHO) pada tahun 2001 mendesak semua negara anggota untuk memulai kampanye kesadaran dan edukasi kepada pasien dan masyarakat mengenai penggunaan antibiotik yang tepat untuk melawan resistensi antibiotik (WHO, 2001). Beberapa penelitian mengenai pengetahuan masyarakat telah dilakukan di dunia (Widayati et al., 2012; Lim et al., 2012; Qamar et al., 2014). Sebuah penelitian di Yogyakarta menunjukan hal yang tidak jauh berbeda yaitu hanya $34 \%$ mempunyai pengetahuan yang cukup (Widayati et al., 2012). Penelitian juga telah dilakukan di Putra Jaya Malaysia, hasilnya mendapati bahwa pengetahuan masyarakat di daerah tersebut terhadap antibiotik masih harus terus ditingkatkan karena tingkat pengetahuannya masih tergolong rendah (Lim et al., 2012). Penelitian lain di Malaysia menunjukkan sebanyak $43 \%$ dari responden mempunyai pengetahuan yang baik mengenai antbiotik walaupun masih banyak yang harus ditingkatkan (Qamar et al., 2014). Tujuan dari penelitian ini adalah untuk mengetahui pengetahuan, kepercayaan dan persepsi masyarakat di Kota Medan terhadap penggunaan antibiotik.

\section{Metode Penelitian}

Penelitian ini merupakan penelitian Cross sectional dan dianalisis secara deskriptif untuk menilai pengetahuan, persepsi dan kepercayaan masyarakat terhadap penggunaan antibiotik. Data diambil pada kelompok masyarakat yang hadir pada acara pengabdian masyarakat yang diadakan di Lapangan Merdeka Kota Medan. Sebuah kuisioner dipersiapkan untuk mengumpulkan data yang meliputi 4 pertanyaan bagian demografi data termasuk jenis kelamin, umur, pendidikan dan pekerjaan), 14 pertanyaan mengenai pengetahuan terhadap antibiotik, 5 pertanyaan mengenai persepsi terhadap antibiotik dan 4 pertanyaan mengenai kepercayaan masyarakat terhadap antibiotik. Semua kuisioner diadaptasi dari penelitian terdahulu (Widayati et al., 2012; Lim et al., 2012; Qamar et al., 2014). Analisa data dilakukan menggunakan metode statistik deskriptif dengan bantuan program Microsoft Excel dan disajikan dalam bentuk tabel dan frekuensi

\section{Hasil dan Pembahasan}

\subsection{Karakteristik Responden}

Sebanyak 98 responden terlibat dalam penelitian ini, wanita sebanyak $50(51 \%)$ responden dan lelaki $48(49 \%)$ responden. Berdasarkan usia, responden yang terlibat mayoritas berusia 43-54 tahun 36 (36,7 \%) diikuti mereka yang berusia 31-42 tahun (25,5\%) dan 19-30 tahun (23,5\%). Berdasarkan tingkat pendidikan, mayoritas responden yang terlibat mempunyai tingkat pendidikan perguruan tinggi 44 (44,9\%) responen dan SMA sebanyak $40(40,8)$ resonden. Mayoritas mereka bekerja sebagai wiraswasta $43(43,9 \%)$ responden. Tabel lengkap dapat dilihat pada Tabel 1 .

Tabel 1 Data Karakteristik responden (n: 98)

\begin{tabular}{ccc}
\hline Variabel & Jumlah (n) & Persen (\%) \\
\hline Jenis kelamin & 48 & 49 \\
Lelaki & 50 & 51 \\
Wanita & & 23,5 \\
Usia & 23 & 25,5 \\
$19-30$ & 25 & 36,7 \\
$31-42$ & 36 & 14,3 \\
$43-54$ & 14 & \\
$55-67$ & & 4,1 \\
Tingkat pendidikan & 4 & 10,2
\end{tabular}




$\begin{array}{ccc}\text { SMA } & 40 & 40,8 \\ \text { Kuliah } & 44 & 44,9 \\ \text { Pekerjaan } & & \\ \text { PNS } & 11 & 11,2 \\ \text { Wiraswasta/bekerja sendiri } & 43 & 43,9 \\ \text { Ibu Rumah Tangga } & 27 & 27,6 \\ \text { Pensiunan/Tidak Bekerja } & 9 & 8,2 \\ \text { Pelajar } & 8 & 9,2\end{array}$

\subsection{Pengetahuan responden terhadap Antibiotik}

Tabel 2 menunjukkan bahwa dari 14 pertanyaan mengenai pengetahuan terhadap antibiotik diperoleh bahwa pengetahuan responden sangatlah rendah. Hal ini dapat dilihat bahwa 12 dari 14 pertanyaan, tidak lebih dari $60 \%$ responden mengetahui mengenai pernyataan yang benar berkaitan antibiotik.

Sebanyak $82(83,7 \%)$ responden mengetahui bahwa antibiotik merupakan obat yang digunakan untuk membunuh bakteri, tetapi hanya $16(16,3 \%)$ dari mereka mengetahui bahwa antibiotik tidak dapt digunakan untuk membunuh virus. Penelitian ini tidak jauh berbeda dengan penelitian yang lain di Yogyakarta, Putra Jaya dan Shah Alam, mayoritas dari mereka mengetahui bahwa antibiotik digunakan untuk membunuh bakteri $(76 \% ; 78,3 \%$ dan $80,3 \%$ ), manakala sebanyak $71 \%, 83 \%$ dan $60 \%$ responden tidak mengetahui bahwa antibiotik tidak digunakan untuk membunuh virus (Widayati et al., 2012; Lim et al., 2012; Qamar et al., 2014).

Dalam penggunaannya antibiotik hanya sebanyak 14 (14,3\%) dari mereka mengetahui bahwa antibiotik tidak digunakan untuk mengatasi fllu, pilek serta batuk, dan hanya $34(34,7 \%)$ mengetahui bahwa antibiotik tidak harus digunakan sebaik demam. Begitu juga hanya 41 (41,8\%) mereka yang mengetahui bahwa antibiotik bukan merupakan obat penghilang rasa sakit dan demam. Penelitian ini menunjukan hal yang sama dengan penelitian di laporkan oleh Widayati et al di Yogyakarta dimana hampir 50\% masyarakat salah paham dan berpendapat bahwa anntibiotik harus diberikan sebaik demam (Widayati et al., 2012). Penelitian di Putra Jaya juga tidak jauh berbeda $82 \%$ berpendapat bahwa antibiotik dapat digunakan untuk mengatasi flu dan batuk (Lim et al., 2012).

Mengenai efek sampingnya tidak sampai dari $60 \%$ dari pasien mengetahui bahwa antibiotik dapat menyebabkan alergi dan mempunyai efek samping. Hal ini sejalan dengan penelitian di Yogyakarta dan Putra Jaya tetapi lebih baik dibandingkan penelitian ini (70\% dan 82,5\%) (Widayati et al., 2012; Lim et al., 2012). Hasil penelitian yang kami lakukan tidak berbeda dengan hasil penelitian yang dilakukan di Shah Alam, Malaysia (Qamar et al., 2014). Penelitian ini mendapati bahwa separuh responden mengetahui bahwa antibiotik juga dapat membunuh bakteri normal yang baik pagi pencernaan (51,6\%), hal ini mempunyai hasil yang lebih baik dari penelitian kami $(45,9 \%)$.

Pada penelitian ini mendapati bahwa sebanyak $65,3 \%$ responden menyadari bahwa penggunaan antibiotik yang berlebih dapat menyebabkan antibiotik tidak efektif, hasil ini lebih baik dari penelitian yang dilakukan di Shah Alam (50\%) (Qamar et al., 2014). Tapi, hanya kurang dari $50 \%$ yang mengetahui bahwa antibiotik bermasalah jika langsung dihentikan sebaik keluhan hilang dan yang menyadari antibiotik yang lebih sedikit tidak selalu lebih baik dibandingkan menggunakan antibiotik dari seluruh jumlah yang diresepkan. Hasil ini lebih baik dibandingkan penelitian yang dilakukan di Shah Alam yaitu 24,2\% dan 12,9 \% secara berurutan (Qamar et al., 2014)

Tabel 2. Pengetahuan responden mengenai antibiotic

\begin{tabular}{llccc}
\hline No. & Pertanyaan & Ya & Tidak & Tidak Tahu \\
\hline 1 & Antibiotik adalah obat yang digunakan untuk membunuh bakteri & $82(83.7)$ & $6(6.1)$ & $10(10.2)$
\end{tabular}


2

Antibiotik dapat digunakan untuk mengobati penyakit yang disebabkan oleh virus

3

Antibiotik dapat digunakan untuk mengatasi penyakit flu, pilek atau batuk

$4 \quad$ Antibiotik harus digunakan sebaik menderita demam

5 Antibiotik dapat membunuh bakteri normal yang hidup di dalam saluran pencernaan

6 Bakteri yang normal hidup dalam saluran pencernaan baik untuk kesehatan

7

Antibiotik adalah obat yang digunakan sebagai penghilang rasa sakit dan demam

8

Penisillin merupakan antibiotik

9

10

11

Penggunaan antibiotik yang berlebihan atau tidak sesuai

dapat menyebabkan antibiotik menjadi tidak efektif atau resisten

12

Tidak masalah jika antibiotik dihentikan ketika keluhan

penyakit telah hilang

13

Penggunaan antibiotik kurang dari yang diresepkan adalah

lebih baik daripada jumlah keseluruhan yg diresepkan

14 Antibiotik yang baru atau yang mahal lebih baik digunakan

\begin{tabular}{|c|c|c|}
\hline $64(65.3)$ & $16(16.3)$ & $18(18.4)$ \\
\hline $75(76.5)$ & $14(14.3)$ & $9(9.2)$ \\
\hline $40(40.8)$ & $34(34.7)$ & $24(24.5)$ \\
\hline 45 (45.9) & $22(22,4)$ & $31(31,6)$ \\
\hline 57 (58.2) & $10(10,2)$ & $31(31,6)$ \\
\hline $41(41.8)$ & $41(41,8)$ & $16(16,3)$ \\
\hline $51(52)$ & $19(19,4)$ & $28(28,6)$ \\
\hline $53(54.1)$ & $21(21,4)$ & $24(24,5)$ \\
\hline $46(46.9)$ & $20(20,4)$ & $32(32,7)$ \\
\hline $64(65.3)$ & $8(8,2)$ & $26(26,5)$ \\
\hline $40(40.8)$ & $36(36,7)$ & $22(22,4)$ \\
\hline $20(20.4)$ & $47(48,0)$ & $31(31,6)$ \\
\hline $25(25.5)$ & $51(52,0)$ & $22(22,4)$ \\
\hline
\end{tabular}

\subsection{Kepercayaan Responden terhadap Antibiotik}

Tabel 3 menunjukkan mengenai pernyataan yang berkaitan dengan kepercayaan masyarakat mengenai antibiotik. Berdasarkan hasil penelitian diperoleh bahwa sebanyak 41,9\% responden mempunyai kepercayaan yang keliru bahwa antibiotik dapat menyembuhkan penyakit apapun, sebanyak 32,7\% tidak yakin dan hanya 25,6\% yang menyatakan bahwa antibiotik bukan obat yang dapat menyembuhkan penyakit apapun. Lebih dari $70 \%$ responden percaya bahwa antibiotik dapat digunakan sebagai obat mencegah penyakit menjadi lebih buruk, sebanyak $13,2 \%$ tidak yakin dan $8,2 \%$ tidak setuju.

Sebanyak 44,9\% dari responden mempunyai kepercayaan mengenai antibiotik serbuk dapat digunakan sebagai obat luka dikulit, sebanyak $36,7 \%$ respoden tidak yakin dan hanyak 18,4\% yang tidak setuju. Jika luka dikulit disebabkan infeksi harus diobati dengan antibiotik, maka antibiotik yang tepat digunakan adalah yang dalam bentuk salep. Berdasarkan penelitian diperoleh banhwa sebanyak 33,7\% setuju bahwa antibiotik tidak mempunyai efek samping, hanya 30,6 \% dari responden yang percaya bahwa antibiotik juga mempunyai efek samping.

Hal ini tidak jauh berbeda dengan penelitian di Yogyakarta yang menunjukan 40\% percaya bahawa antibiotik dapat menyembuhkan penyakit apapun, begitu juga dengan pernyataan bahwa antibiotik dapat mencegah penyakit menjadi lebih buruk (74\%). Penelitian ini juga menunjukan bahwa sebanyak $37 \%$ responden percaya bahwa antibiotik serbuk dapat digunakan sebagai obat luka dikulit dan $24 \%$ percaya bahawa antibiotik tidak mempunyai efek samping (Widayati et al., 2012). Hal ini menunjukan kepercayaan masyarakat terhadap antibiotik masih banyak yang keliru dan harus terus diperbaiki. Kekeliruan terhadap pengetahuan dan kepercayaan terhadap antibiotik inilah yang dapat menyebabkan resistensi terhadap antibiotik. 
Tabel 3. Kepercayaan Masyarakat Terhadap Antibiotik

\begin{tabular}{clcccc}
\hline No & \multicolumn{1}{c}{ Pernyataan } & Sangat Setuju & Setuju & Tidak yakin & $\begin{array}{c}\text { Tidak Setuju } \\
\text { Sangat } \\
\text { tidak setuju }\end{array}$ \\
\hline 1 & $\begin{array}{l}\text { Saya Percaya bahwa antibiotik dapat } \\
\text { menyembuhkan penyakit apapun }\end{array}$ & $13(13.3)$ & $28(28.6)$ & $32(32.7)$ & $21(21.4)$ \\
2 & $\begin{array}{l}\text { Saya percaya antibiotik dapat } \\
\text { mencegah penyakit agar tidak menjadi lebih } \\
\text { buruk }\end{array}$ & $19(19.4)$ & $58(59.2)$ & $13(13.2)$ & $5(5.1)$ \\
3 & $\begin{array}{l}\text { Saya percaya luka yang terdapat di kulit } \\
\text { lebih cepat sembuh dengan menaburkan } \\
\text { antibiotik serbuk ke luka }\end{array}$ & $13(13.3)$ & $31(31.6)$ & $36(36.7)$ & $15(15.3)$ \\
& $\begin{array}{l}\text { Saya percaya antibiotik tidak } \\
\text { mempuntai efek samping }\end{array}$ & $9(9.2)$ & $24(24.5)$ & $35(35.7)$ & $24(24.5)$ \\
\end{tabular}

\subsection{Persepsi Responden terhadap Antibiotik}

Tabel 4 menunjukkan mengenai pernyataan yang berkaitan dengan persepsi masyarakat terhadap antibiotik. Berdasarkan hasil penelitian dapat dilihat bahwa persepsi masyarakat terhadap antibiotic maih rendah, hal ini karena hanya sebanyak kurang dari $40 \%$ responden yang mempunyai persepsi yang benar mengenai penggunaan antibiotik seperti tidak segera menggunakan antibiotik jika flu, tidak segera menghentikan antitibiotik ketika sembuh, tidak meminta dokter meresepkan jika ada gejala flu dan tidak menyimpankan antibiotik sebagai persediaan.

Persepsi masyarakat dalam penelitian ini menunjukan kondisi yang sama dengan persepsi masyarakat di Putra Jaya dan Shah Alam. Pada kedua penelitian juga menunjukan kurang dari $50 \%$ responden menunjukan persepsi yang benar mengenai persepsi mengenai penggunaan antibiotik ketika flu atau pilek, antibiotik dapat dihentikan jika merasa sembuh dan meminta dokter meresepkan antibiotik jika mengalami gejala flu. Tetapi kedua penelitian ini menunjukan persepsi yang baik dibandingkan penelitian kami mengenai antibiotik dapat dikongsi dengan anggota keluarga dan kebiasaan menyimpan antibiotik sebagai persediaan ketika darurat (Lim et al., 2012; Qamar et al., 2014).

Tabel 4. Persepsi Responden Terhadap Antibiotik

\begin{tabular}{|c|c|c|c|c|c|c|}
\hline No & Pernyataan & Sangat Setuju & Setuju & Tidak yakin & Tidak Setuju & $\begin{array}{l}\text { Sangat } \\
\text { tidak setuju }\end{array}$ \\
\hline 1 & $\begin{array}{l}\text { Ketika flu atau pilek saya akan segera } \\
\text { menggunakan antibiotik }\end{array}$ & $8(8,2)$ & $28(28.6)$ & $\begin{array}{c}28 \\
(28,6)\end{array}$ & $\begin{array}{c}29 \\
(29,6)\end{array}$ & $5(5,1)$ \\
\hline 2 & $\begin{array}{l}\text { Saya biasa menghentikan antibiotik jika } \\
\text { sudah merasa sembuh }\end{array}$ & $\begin{array}{c}17 \\
(17,3)\end{array}$ & $\begin{array}{c}37 \\
(37,8)\end{array}$ & $\begin{array}{c}17 \\
(17,3)\end{array}$ & $\begin{array}{c}24 \\
(24,5)\end{array}$ & $3(3.1)$ \\
\hline 3 & $\begin{array}{l}\text { Jika mempunyai gejala flu saya akan minta } \\
\text { dokter meresepkan antibiotik }\end{array}$ & $7(7,1)$ & $\begin{array}{c}27 \\
(27,6)\end{array}$ & $\begin{array}{c}25 \\
(25,5)\end{array}$ & $\begin{array}{c}34 \\
(34,7)\end{array}$ & $5(5,1)$ \\
\hline 4 & $\begin{array}{l}\text { Jika ada anggota keluarga saya sakit, } \\
\text { biasanya saya akan memberikan antibiotik }\end{array}$ & $\begin{array}{c}10 \\
(10,2)\end{array}$ & $\begin{array}{c}30 \\
(30,6)\end{array}$ & $\begin{array}{c}20 \\
(20,4)\end{array}$ & $\begin{array}{c}31 \\
(31,6)\end{array}$ & $7(7.1)$ \\
\hline 5 & $\begin{array}{l}\text { Saya biasa menyimpan antibiotik untuk } \\
\text { persediaan }\end{array}$ & $\begin{array}{c}10 \\
(10,2)\end{array}$ & $\begin{array}{c}36 \\
(36,7)\end{array}$ & $\begin{array}{c}12 \\
(12,2)\end{array}$ & $\begin{array}{c}33 \\
(33,7)\end{array}$ & $7(7.1)$ \\
\hline
\end{tabular}




\section{Kesimpulan}

Berdasarkan hasil penelitian menunjukan bahwa pengetahuan masyarakat masih harus terus ditingkatkan karena masih rendahnya pengetahuan dan kesalahpahaman mengenai persepsi dan kepercayaan pada penggunaan antibiotik. Selanjutnya, perlu kerja keras dari semua unsur masyarakat dan pemerintah untuk meningkatkan pengetahuan masyarakat sehingga dampak negatif dari kesalahan penggunaan antibiotik berupa resistensi dapat dikurangkan.

\section{Daftar Pustaka}

[1] Andre M, Vernby A, Berg J, Lundborg CS: A survey of public knowledge and awareness related to antibiotic use and resistance in Sweden. J Antimicrob Chemother 2010, 65 (6):1292-1296.

[2] Franco BE, Altagracia Martínez M, Sánchez Rodríguez MA, Wertheimer AI. The determinants of the antibiotic resistance process. Infect Drug Resist. 2009; 2: 1 - 11 .

[3] Goossens H, Ferech M, Stichele RV, Elseviers M for the ESAC Project Group. Outpatient antibiotic use in Europe and association with resistance: a cross-national database study. Lancet. 2005 February 12; 365(9459): 579 - 587.

[4] Grigoryan L, Burgerhof JG, Degener JE, Deschepper R, Lundborg CS,Monnet DL, Scicluna EA, irkin J, Haaijer-Ruskamp FM: Attitudes, beliefs and knowledge concerning antibiotic use and selfmedication:a comparative European study. Pharmacoepidemiol Drug Saf 2007,16(11):1234-1243.

[5] Lim KK, Teh CC. A Cross Sectional Study of Public Knowledge and Attitude towards Antibiotics in Putrajaya, Malaysia. Southern Med Review 2012; 5 (2): 26-33

[6] Qamar M, Sheikh Abdullah NH, Khan J, Mahmud A, Ahma A. Knowledge and Attitude Towards Antibiotic Usage Among General Public in Shah Alam, Malaysia, UK Journal of Pharmaceutical and Biosciences 2014.. 2(6), 60-66.

[7] Radyowijati A, Haak H: Improving antibiotic use in low-income countries: an overview of evidence ondeterminants. Soc Sci Med 2003, 57: 733-744.

[8] Widayati A, Suryawati S, Crespigny CD, Hille JE. Knowledge and beliefs about antibiotics among people in Yogyakarta City Indonesia: a cross sectional population-based survey. Antimicrobial Resistance and Infection Control 2012,1:38.

[9] World Health Organization WHO/CDS/CSR/DRS/2001.2. WHO Global Strategy for Containment of Antimicrobial Resistance. Switzerland: World Health Organization; 2001. Diakses pada 10 Agustus 2016. http://www.who.int/drugresistance/WHO_Global_Strategy_English.pdf 